\title{
Productive efficiency and the future of regional disparities in Brazil
}

Eficiência produtiva e o futuro das disparidades regionais no Brasil

\author{
Daniela Schettini (1) \\ Carlos Roberto Azzoni (2) \\ (1) Universidade de São Paulo \\ (2) Universidade de São Paulo
}

\begin{abstract}
We use Stochastic Production Frontiers to estimate the recent levels and the evolution of productive efficiency across regions in Brazil. Results are available for agriculture, industry and services, as well as for total production. We observe a substantive efficiency growth exhibited by agriculture at the national level, which is counterbalanced by the poor performance of services. The regional results show that efficiency levels still replicate, in general, the regional inequality that marked the country's history through decades. However, the efficiency growth reveals new signs of convergence among states, especially for industry, with effects on the aggregate production. This indicates that inequality trends in productive efficiency may be starting to change.
\end{abstract}

\section{Keywords}

\section{Palavras-chave}

Productivity; Regional Inequality; Regional; Regional Productivity Growth.

Produtividade; desigualdade regional; regional; crescimento da produtividade regional.

JEL Codes R11; R12.

Códigos JEL R11; R12. 


\section{Introduction}

Brazil is a well-known case of a large country displaying quite stable levels of regional concentration and regional inequality (Baer, 2007; Azzoni; Haddad, 2018). ${ }^{1}$ In 2014, the Northeast region hosted $28 \%$ of the population, and less than $13 \%$ of the GDP, and is thus the most visible aspect of the "regional problem" in the country, given its political influence. The South and Southeast regions are richer, accounting for $74 \%$ of GDP in 2014, and 56\% of population. In the last three decades of the $20^{\text {th }}$ century, some important changes occurred, mainly within the North and Midwest regions, with the expansion of the agricultural and mining frontiers. The first region more than doubled its share in population and doubled its share in GDP, based on logging and mining activities, and cattle ranching. The second more than tripled its share in population, and multiplied by a factor of more than four times its share in GDP, led by the expansion of the agricultural frontier and the establishment of the nation's capital (Brasília) in the region. Even with those events, the levels of disparity have not changed substantially. Monasterio and Reis (2008) indicate that as far back as 1872 the levels of disparities were similar to the present situation.

However, changes occurred in the first decade of the $21^{\text {st }}$ century in the economic environment within which its regional economies operate that have potential to introduce important elements to change the longlasting disparity scenario. These changes include the opening up of the economy, the reduction and stabilization of the inflation, with differentiated influence in space according to the concentration of poor population, the real growth of the minimum wage, the important social programs of income transferences ${ }^{2}$ associated to a growth path led by internal consumption and the favorable scenario of commodity prices experienced in the first decade of this century (Ferreira et al., 2006; Silveira-Neto; Azzoni, 2011 and 2012). The reversal of the commodity prices trends, in conjunction with the inefficacy of the internal economic policy, as well

1 Webber et al. (2009) shows the same situation for England; Gallo and Dall'erba (2008) analyzes regional convergence of productivity across European regions.

2 As De Negri and Cavalcante (2014) point out. Soares et al. (2009) show that income transference programs were responsible for one-third of the inequality reduction observed from 2004 to 2006. 
as the political unrest associated with it, led to a serious recession, now in its fourth year in a row, with zero or negative GDP growth rates. This could also produce structural changes with regional repercussions, but it is too early to judge.

Regional inequality within a country is produced by decades of differences in competitiveness among its regions, and changes in this scenario can only come out if the relative competitiveness of regions is altered in a significant way. Studies of regional performance typically use data on GDP, employment or investment shares. These are relevant aspects to be considered, but they only inform on the established competitiveness scenario resulting from decisions taken by productive units in the past. Following the trend in GDP shares to predict future competitiveness could be misleading, for the regional distribution of new investments is not considered. This paper assumes that the future regional distribution of investments follows the recent regional distribution of competitiveness and that it is influenced by its trend. In deciding on where to invest, entrepreneurs take into account the observed levels of productivity, and its recent evolution.

As such, regional competitiveness is a better indicator of the future evolution of regional shares in GDP than the regional shares. Productivity is a major indicator of competitiveness and sustainable economic growth (Kaldor, 1970; Jacinto; Ribeiro, 2015). This sets the background for this investigation, which is intended to measure the productivity levels of its regions and how they have changed in recent years. We provide estimates of productive efficiency levels and trends for the period 2000-2014 for three broad sectors of activities - agriculture, industry (manufacturing and extractive) and services -, as well as for aggregated production.

Most authors reviewed produced results only for specific sectors, without considering events occurring in other parts of the economy. This paper contributes to the literature by producing indicators of efficiency levels and efficiency trends for the three broad sectors of economic activity simultaneously. We bring information for a period of 15 years after the turn of the century, thus providing evidence on a more recent period, one in which important changes in the national economy were present. We use Stochastic Frontiers to estimate the efficiency levels, which is also not common in the literature on Brazil. In line with the recent literature on regional studies, we introduce spatial effects in the estimations. Finally, 
we deal with states, thus providing a fine geographical disaggregation of the national results.

The paper is organized in seven sections. After this introduction, section 2 reviews the literature on the measurement of efficiency at the national level in the country. Section 3 presents the methodology used to obtain regional productivity estimates by sector. Section 4 shows the data and presents the descriptive statistics. Section 5 discusses the estimated levels and growth rates of productive efficiency. Section 6 debates the possible existence of regional efficiency convergence. Finally, section 7 concludes the paper.

\section{Efficiency in the Brazilian economy}

Many studies indicate very low, or even negative, growth rates of the Total Factor Productivity (TFP) for the country during recent decades (Gomes et al., 2003; Bonelli; Veloso, 2012; Bonelli; Bacha, 2013; Ferreira; Veloso, 2013). In the 2000s, the studies agree in observing productivity growth, especially from 2008-2010, but at a low pace. From 2010 on, there was even a decrease or close to zero evolution, as a reflection of the world economic crisis (Bonelli, 2014). De Negri and Cavalcante (2014) explain that, contrary to what happened during the 90 s, just half of the per capita GDP growth during 2001-2009 could be explained by productivity gains. According to IPEA (2012), these gains were mostly due to the performance of agriculture. In fact, this sector is a relevant case to look at, given the success of the country in terms of expanding its market share in the international markets. TFP grew at around $2.3 \%$ per year in the 1980 s, $3.37 \%$ in the 1990s and 4.7\% from 2000 to 2008 (Bragagnolo et al., 2010; Brigatte; Teixeira, 2012; Gasques et al., 2012).

Most studies analyze productivity at the country level, but very few are able to include the regional dimensions of the problem. Agriculture received the attention of several researchers. Gasques and Conceição (2000) and Gasques et al. (2004a, 2004b) verified that nontraditional states in the Center-West (MT and $\mathrm{MS}^{3}$ ) and Northeast (PI and CE) were the area that enhanced TFP growth in agriculture between 1985 and 1995. Marinho and 
Carvalho (2004), despite confirming the result for the Center-West and adding the South, do not agree with the good result for the Northeast. Vicente (2011) estimated TFP and efficiency in agriculture in Brazilian states and verified regional convergence of TFP levels between 1995 and 2006, but the states of the poor North and Northeast regions continued to present lower-than-average TFP performance. Felema et al. (2013), using data from the 2006 Census of Agriculture, confirmed the low performance of those regions and the positive situation of the South and Center-West regions. Bragagnolo et al. (2010) used a Stochastic Frontier model to estimate agricultural efficiency for Brazilian states from 1975 to 2006. They concluded that strong technical progress and positive efficiency growth were responsible for expanding the agricultural frontier in the Northeast and Center-West regions. Without specifying any region, Gasques et al. (2004a, 2004b and 2013), Gray et al. (2011), Vieira Filho et al. (2005) and Gonçalves and Neves (2007) suggest that intense technological innovations and research, reductions in the labor/capital ratio and improvements in seeds, fertilizers and pesticides were responsible for the substantial TFP growth observed in agriculture.

Studies for manufacturing at the national level stress the high impact of trade liberalization and monetary stabilization on TFP during the 1990s (Kupfer, 1998; Quadros et al., 1999; Feijó; Carvalho, 2002; Rossi; Ferreira, 1999; Bonelli; Fonseca, 1998). According to Bonelli (1992) and Rossi and Ferreira (1999), TFP had an annual increase of 0.8\% from 1975 to 1985 and $2.15 \%$ from 1991 to 1997 . Recent estimates, however, show a decline in performance. Barbosa Filho et al. (2010) observed an annual TFP growth of only $0.72 \%$ from 1992 to 2007 . Squeff (2012) compares the GDP per capita growth of $1.9 \%$ per annum from 2000 to 2009 to the labor productivity growth of the economy of $0.8 \%$; productivity in manufacturing decreased $1.2 \%$ per year, leaving to agriculture and services the job of keeping the path of aggregate productivity growth in recent years. Messa (2015) estimates a sharper drop of $1.68 \%$ per year from 2002 to 2010. Galeano and Wanderley (2013) separate the industry estimates between manufacturing and extractive activities and conclude that as the former exhibits decreases in labor productivity from 1996 to 2010, the latter increased its performance. As for the regional dimensions of manufacturing, Schettini and Azzoni (2013) indicate that the traditional manufacturing centers are the ones with the highest productivity levels, and that 
there are no significant signs of changes in this situation between 2000 and 2006. Galeano and Wanderley (2013) consider that despite having enhanced its competitiveness due to trade liberalization, the poor Northeast region presented the lowest labor productivity indicators in 2010, compared to other regions.

Finally, some studies on the service sector highlight the great heterogeneity of its activities, which affect the estimation of productivity (Arbache, 2015; Nogueira et al., 2014; Jacinto; Ribeiro, 2015). Arbache (2015) emphasizes the low performance of this sector and indicates labor productivity growth between 1998 and 2000, followed by a decline from 2000 to 2005, turning positive again since then. Jacinto and Ribeiro (2015) argue that services performed better than manufacturing in the 2000s. Labrunie and Saboia (2016) go further, affirming that the positive results may have contributed to gains in productivity in manufacturing. Given the recognized heterogeneity of services, results vary substantially across sub-sectors. Technology-intensive sub-sectors are expected to present high rates of productivity growth, and they usually have a low proportion of labor employed, which may explain the positive performance of the service sector.

According to McMillan and Rodrik (2011), developing countries tend to show asymmetry of productivity indicators across economic sectors. As indicated by the results shown above, this seems to be the case in Brazil. Therefore, it is important to consider the different performance of sectors in analyzing aggregate productivity growth. On the other hand, regions are heterogeneous and develop at different paces. Estimating productivity by states provides information on the levels and evolution of regional inequalities. This is the standpoint of this paper, since we consider levels and evolution of productive efficiency in three sectors across regions in Brazil. We use a panel of 27 regions for the period 2000-2014 to estimate the levels and growth of productivity for agriculture, industry and services.

\section{Methodology}

According to Bonelli (1996), productivity can be defined as the ratio between the output (goods or services) and the inputs used in the production process, resulting in a Total Factor Productivity indicator. The neoclassical 
theory considers two main productivity measures: i) marginal productivity, when only one factor of production is contemplated and ii) TFP, which accounts for all the factors of production, in addition to the efficiency in the production process. Thus, the TFP reflects improvements in technology, organization of production and change in the use rate of resources and their efficiency.

Economic efficiency is the result of two components: i) technical efficiency - maximization of output, given a level of inputs and ii) allocative efficiency, which is the ability to combine output and input in great proportions, according to their prices (Farrel, 1957). The technical efficiency, which is also called productive efficiency in the literature, is an indicator obtained through the use of Stochastic Frontiers, and relates observed inputs and outputs to an optimal performance. Several authors investigated the different types of efficiency and the decomposition of productivity changes in technical and allocative changes and technological frontier shifts (Balk, 2001; Lovell, 1993; Färe et al., 1994). From this debate, it is possible to establish a direct relationship between economic efficiency (and each one of its components) and productivity (TFP). Other factors remaining constant, an increase in technical or allocative efficiency leads to an increase in productivity.

In this article, we use the technical efficiency given by the Stochastic Frontier methodology as a measure of productivity. We use Stochastic Frontier Analysis, originally developed by Aigner et al. (1977) and Meeusen and Van Den Broeck (1977) to estimate regional productive efficiency. For each sector, the general estimated model is:

$$
\begin{aligned}
& y_{i t}=\beta_{0}+\beta_{1} L_{i t}+\beta_{2} K_{i t}+\beta_{3} t+\sum_{j=2}^{3} \beta_{j+2} d s_{j}+\sum_{k=2}^{3} \beta_{k+4} t_{k} \\
& \text { +regional_fixed_effects }+ \text { spatial_controls } s_{i t}+\varepsilon_{i t}
\end{aligned}
$$

where GDP is the output, $L_{i t}$ and $K_{i t}$ are the labor and capital inputs, all measured in natural logs. The subscript $i$ represents the units of observation and $t$ represents the year; $d s_{j}$ is the dummy for industry $(\mathrm{j}=2)$ and services ( $j=3$ ); regional fixed effects are 26 state dummies: ${ }^{4} t$ is the general trend, assuming values from 1 to 15 (years 2000 to 2014); $t_{k}$ is the general 426 states plus the Federal District. One regional dummy is dropped to avoid multicollinearity. 
trend interacted with the sectorial dummies $\left(t_{2}\right.$ is the industry trend and $t_{3}$ is the services trend). ${ }^{5}$

The production function indicates the output produced with a given technology and a certain amount of inputs. We use a Cobb-Douglas production function, with the natural logarithm of GDP as the output and the natural logarithm of labor and capital as the inputs. Since we work with panel data (regional sates over time), we add regional and sectoral fixed effects to account for unobservable and constant effects (Greene, 2004a, 2004b). A general trend component and its interactions with sectoral dummies account for the productivity growth rates for each sector.

The error term is the sum of a symmetric random component and a one-sided inefficiency component. ${ }^{6}$ This implies that the productive unit produces according to its production function, but it is subject to some technical inefficiency that takes it away from the frontier. Jondrow et al. (1982) proposed a method to estimate the technical efficiency for each individual, with the indicator varying between zero (minimum efficiency) and one (maximum efficiency).

Finally, since we work with regional data, it is important to check and control for spatial dependence, so we add spatial controls. Franzese and Hays (2007) explain the consequences of estimating non-spatial Ordinary Least Squares in the face of spatial dependence. Ignoring spatial processes in data creates the omitted variable bias, leading to wrong standard errors estimates and the inference invalid (Anselin, 1988; Ward; Gledtisch, 2008; Klotz, 2004). We considered a Spatial X model (SLX), since neighboring independent variables may be affecting the outcome of a certain region. There are six spatial controls, at most, given by the interactions of a spatial weight matrix $\mathrm{W}$ with each input (labor and capital). The spatial controls are also distinct by sectors, through the interaction with sectoral dummies. We use the inverse of the distance between regions as weights.

5 Therefore, we generated three variables: general trend, (trend * dummy for industry) and (trend * dummy for services). When the dummies for industry and services are both zero, the observations belong to agriculture. Therefore, the general tendency shows the annual growth rate in agriculture. When the observation comes from the industry (trend * dummy for services equals zero), the growth rate for industry is the sum of the coefficients of the general trend and (trend ${ }^{*}$ dummy for industry sector). The same logic applies to services. In doing so, we are able to depict productivity growth rates for each sector.

6 The random error component is assumed to be independently and identically distributed, while the inefficiency component can assume different distributions such as half-normal, truncated, exponential and gamma. We use the half-normal distribution. 


\section{Data}

The database is a panel composed of 27 Brazilian states (regions) and three economic sectors (agriculture, industry and services), over the period 20002014, resulting in 1,215 observations. ${ }^{7}$ We use the value added, from the Gross Domestic Product of National Accounts, of each sector/state as the output. The number of employees is the measure of the labor input. For agriculture, we used the censuses of 1996 and 2006, and have interpolated with data from annual surveys; these surveys were also used to extend the series to 2014. For industry and services, we used the population censuses of 2000 and 2010, interpolating the annual values with employment data from yearly surveys on samples of population and firms (PNAD and PIA). 8

Due to the lack of better data, the consumption of electricity is used as a proxy for capital in industry and services. ${ }^{9}$ The proxy for capital in agriculture is the total number of tractors and agricultural machinery. ${ }^{10} \mathrm{We}$ interpolate the stocks measured in the 1996 and 2006 censuses with the annual sales of tractors in each state. ${ }^{11}$ In order to correct for the different

7 As defined by the regional accounts produced by the Brazilian Institute of Geography and Statistics (IBGE), the official statistics office. In our sample, agriculture includes farming and ranching; industry includes manufacturing and extractive activities; services include commerce but exclude public health, social security, education and administration activities.

8 Value added is measured in BRL millions of 2013. PNAD - Pesquisa Nacional por Amostras de Domicílios (National Survey on Samples of Households) and PIA - Pesquisa Industrial Anual (Annual Industrial Survey) are also produced by IBGE. We have used PNAD variations in employment by sector/region to interpolate census data for agriculture and services. For industry, we have applied the value added/labor ratio from PIA to the value added given by the Regional Accounts.

9 For industry, we used the sum of electricity and fuel consumption from PIA. For services we use data from Ipea, Ministry of Planning, and the Statistical Yearbook of Electrical Energy (Ministry of Mines and Energy), measured in GWH. State proportions are based on the consumption of automotive fuel (gasoline, diesel, ethanol), provided by the Agência Nacional de Petróleo, Gás Natural e Biocombustíveis (ANP). Despite limitations, some authors use electricity as a proxy to capital stock (Barreto et al., 1999; Cangussu et al., 2010; Noronha et al., 2010; Figueredo et al., 2003; Nakabashi; Salvato, 2007).

10 Vicente et al. (2001) and Marinho and Carvalho (2004) also use the number of machines.

11 Data from the Yearbook of the Brazilian Automotive Industry of Anfavea (National Association of Automobile Manufacturers). The capital stock in agriculture was constructed with data from the agricultural censuses of 1996 and 2006 and annual sales of tractors from Anfavea. We took the stock registered in the 1996 Census and added the state annual sales through 2006. This produced state stocks for this later year that were different from the ones registered by the 2006 census, resulting in distinct growth rates for each state. In order to generate annual values, we have introduced the yearly oscillations in sales of tractors in each state into the geometric growth rates observed in the between censuses data. We did it in such a way that the number of tractors and agricultural machines in 1996 and 2006 in each state are exactly the same as reported in the censuses, but the oscillations in this stock 
measures of capital (energy, measured in Reais ( $R$ \$) for industry and in Gwh for services, and number of tractors for agriculture), we have included dummy variables for industry and services interacting with capital. ${ }^{12}$ By doing so, we take into account the characteristics of each sector in terms of capital usage. ${ }^{13}$

Table A2 in the appendix shows the evolution of value added (VA), labor $(\mathrm{L})$ and capital $(\mathrm{K})$ at the national level and some descriptive statistics. The high values of the standard errors reveal the great diversity across regions in each sector. Figure 1 exhibits maps displaying value added, labor and capital levels by states in 2014, the last year of our period of analysis, measured in relation to the national average. With few exceptions, it is clear that the Southeastern and Southern states concentrate the economic activity of the country in all sectors.

Table A3 in the appendix details the annual average of labor productivity by state and sector. Shaded cells are states with an above-average labor productivity. This happens mostly in the states of the Southeast, South and Center-West to agriculture and services and Southeast and South to industry. Bahia and Amazonas are the only ones to have above-average labor productivity in industry outside those regions and Rondônia, Acre and Tocantins to agriculture.

from year to year replicate the oscillations in sales observed in each state. From 2006 on, we simply added to the observed stock in 2006 the state annual sales reported by Anfavea. The possibility that tractors could be sold in one state and used in another state is not a problem in the period 1996-2006, since the methodology makes sure the stocks in each state are exactly those reported in the censuses. From 2007 on, this could be a problem. However, the efficiency results would be biased only if some states had systematic tractor trade deficits and others, superavits. Our analysis of the period within censuses indicates that the problem is not important, but we really do not have ways to access how serious of a problem this could be from 2007 on. In any case, we found no better alternative to generating state level series of capital stocks in agriculture.

12 Several empirical tests were made using different measures of capital for each sector before choosing the best model. For instance, energy consumption was also considered for agriculture and services, but it led to poorer results. According to Arbache (2015), who investigated productivity in the Brazilian service sector between 1998 and 2001, 89\% of the firms have from 0 to 10 employees. The subsector of surveillance, security and valuable transportation is the largest in terms of number of employees. This is why we used state fuel consumption to distribute energy consumption in the service sector. Not only did this mean we had consistent data, but also better results.

13 Since we work with a pooled database for the three sectors, the coefficient of capital would represent an average estimate for the three sectors. Since we have different ways of measuring capital across sectors, it is necessary to take that into consideration in the estimations. We did so by interacting capital with sectorial dummies. 
Figure 1 Value added, labor and capital across states, 2014

\section{Value added}

Agriculture

Value Added

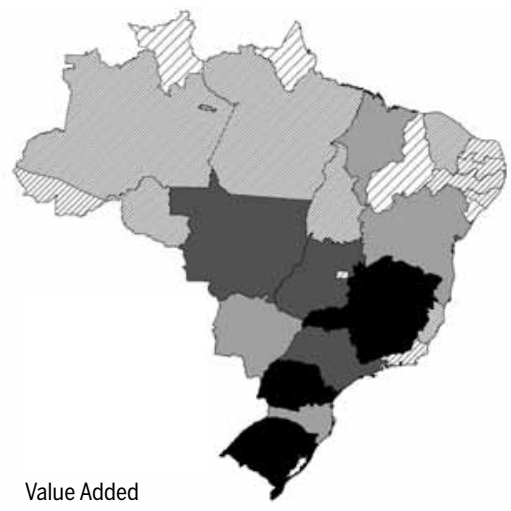

(\% relative to average), 2014

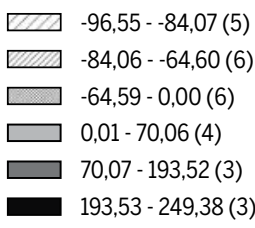

Industry

Value Added

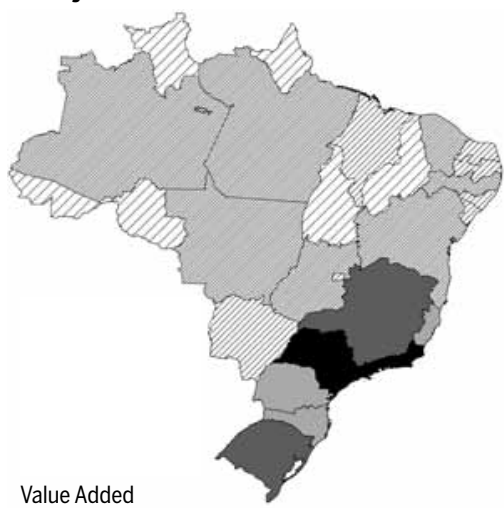

(\% relative to average), 2014

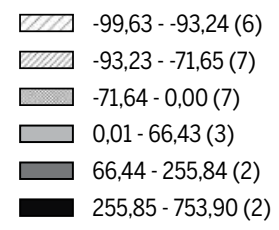

\section{Services}

Value Added

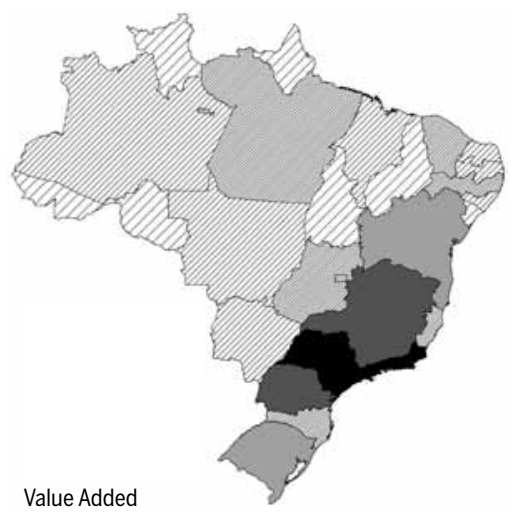

(\% relative to average), 2014

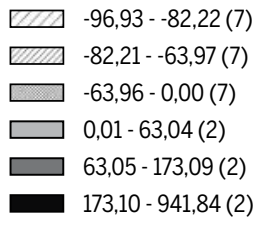




\section{Labor}

\section{Agriculture}

Labor

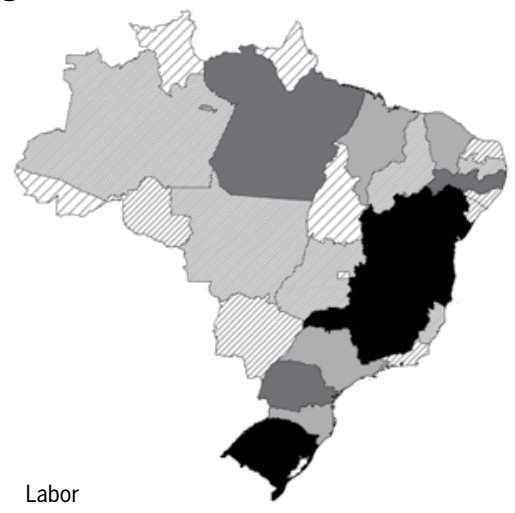

(\% relative to average), 2014

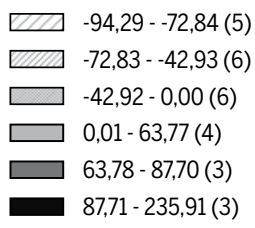

\section{Services}

Labor

\section{Industry}

Labor

(\% relative to average), 2014

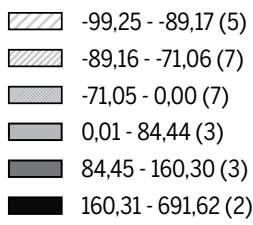

$-99,25--89,17(5)$

$-89,16--71,06(7)$

$-71,05-0,00(7)$

$0,01-84,44(3)$

$160,31-691,62(2)$

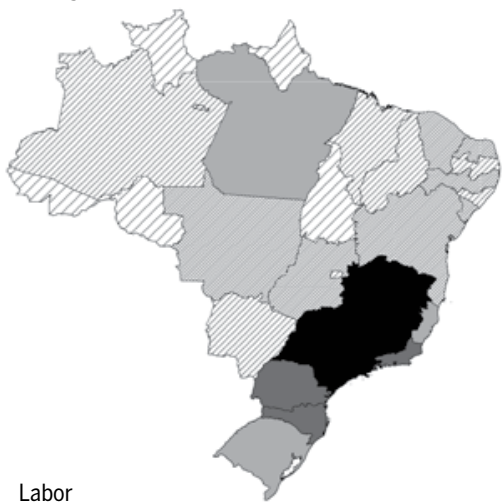

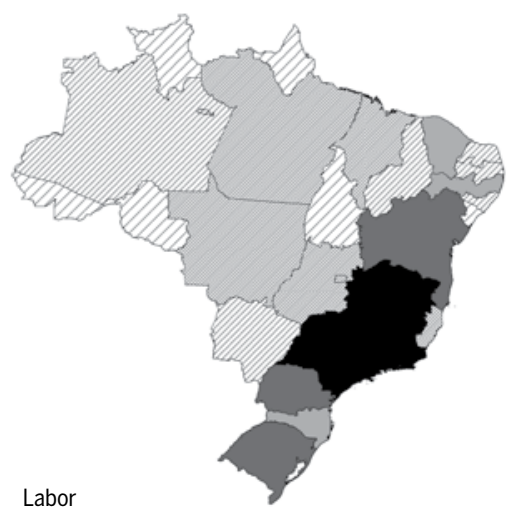

(\% relative to average), 2014

-95,34- - 74,30(6)

$-74,29--56,80(6)$

$-56,79-0,00(6)$

$0,01-42,62(3)$

$42,63-159,54(3)$

159,55 - 596,78(3) 


\section{Capital}

\section{Agriculture}

Capital

(\% relative to average), 2014

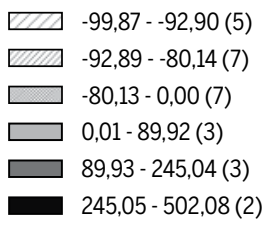

Industry

Capital

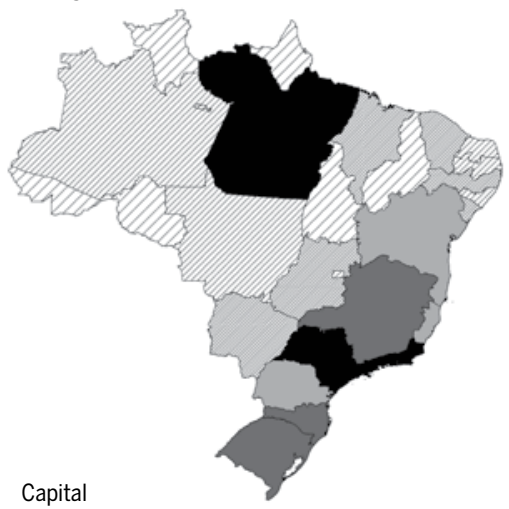

(\% relative to average), 2014

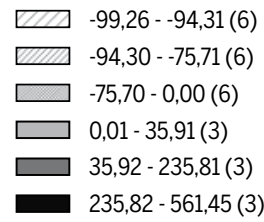

\section{Services}

\section{Capital}

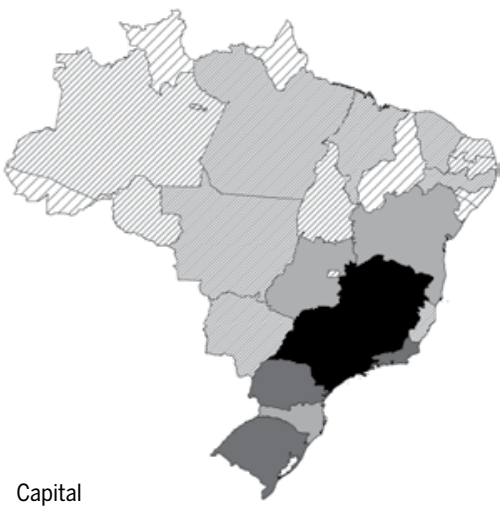

(\% relative to average), 2014

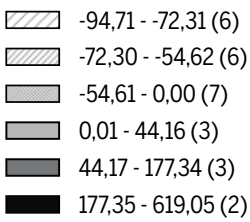

Source: Elaborated by the authors with data from IBGE, Ministry of Mines and Energy and Anfavea. 


\section{Results}

\subsection{National}

Table 1 reports the estimated Cobb-Douglas production function frontiers. The first model includes labor and capital as inputs and a trend effect, to account for national macroeconomic shocks in the economy. Given that we use different proxies for capital across sectors, we have inserted sectoral dummies interacting with capital. ${ }^{14} \mathrm{We}$ also differentiate productivity levels and trends by interacting with the sectoral intercept dummies for industry and services. As such, the general productivity level and trend refers to agriculture; the productivity levels and trends for industry and services are given by adding the respective sectoral dummy coefficients to the general coefficient. ${ }^{15}$

As the results from Model 1 show, the coefficients of labor and capital are significant, with the expected signs and values. The positive and significant trend coefficient indicates the expansion of the agricultural frontier through time. The trend for industry is similar to that of agriculture, and the trend for services is significantly lower. The significant sectoral intercepts (ds2 and ds3) indicate that industry and services present larger productivity levels, as compared to agriculture (constant term). ${ }^{16}$

The residual test for spatial autocorrelation using Moran's I statistic indicates the presence of spatial autocorrelation. Therefore, we added regional fixed effects through intercept dummies to account for unobservable and constant regional effects. We also include two spatial controls as independent variables, as in a SLX spatial model, interacting each input with an inverse distance spatial weight matrix (Model 2). There is no spatial autocorrelation in the residuals of this model, but the spatial controls

14 " 2 " refers to industry and " 3 " to services.

15 In production functions, the constant term is an estimate of the general productivity level. If we had no intercept dummies in the model, the constant would represent the average productivity level for all sectors. By including sectoral intercept dummies, we differentiate the productivity level of each sector. As explained for the sectoral trend, when the dummies for industry and services are both zero, the constant represents the productivity in agriculture. The productivity level for industry is given by the sum of the industry dummy coefficient and the constant. The same goes for services.

16 The estimated productivity level for agriculture is -1.695 , according to Model1. The estimated productivity levels for industry and services are higher, 3.645 and 5.105 (ds2 and ds3 coefficients), respectively. Since we also consider regional fixed effects, the estimated constant coefficient cannot just reflect the agricultural productivity level. 
were not significant. Since Model 1 indicated spatial autocorrelation for agriculture, we differentiate the spatial effects sector by sector (Model 3). The coefficients of interest are not substantively different from those in Models 1 and 2. In Model 3, the general trend coefficient indicates that efficiency in agriculture is growing (1.3\% per year); the estimated trend for industry, although with a negative coefficient (- $0.3 \%$ per year), is not statistically different from that of agriculture. The trend coefficient for services is significantly lower that for agriculture, and shows a negative value $(1.3 \%-2.9 \%=-1.6 \%)$.

The results indicate that a $1 \%$ increase in labor causes an increase of $0.58 \%$ in output. An increase of $1 \%$ in capital leads to an increase of $0.67 \%$ in output for services $(0.428+0.240), 0.52 \%$ for industry $(0.428$ +0.089 ) and $0.43 \%$ for agriculture (0.428). This is our preferred specification and it will be the one employed in the subsequent regional and sectoral analysis. The intercept dummies for the sectors (ds2 and ds3) indicate that the annual average levels of productivity for industry and services are higher than that of agriculture. ${ }^{17}$ However, the frontier for agriculture expands at a faster pace compared to the other sectors (although the difference to industry is not significant). This suggests a sort of productive convergence within sectors. The general trend coefficient indicates that agriculture experienced the strongest productivity growth in the period, $1.3 \%$ per year.

A direct comparison of our results with those presented by other studies is not straightforward. We use both capital and labor as inputs, while the majority of analyses are based on a partial concept of productivity, value added per worker. Moreover, we use state-level data to estimate the national results, which is distinct from the majority of the studies revised. Another source of difficulty is the fact that we estimate the three sectors simultaneously, while all of the studies reviewed produce estimates for individual sectors. A fourth issue lays on the periods considered, which do not match ours. In spite of these methodological differences, our results are in line with the main findings of those studies at the national level.

The results for agriculture are compatible, in general terms, with the literature presented in the introduction. Gasques et al. (2014), estimating TFP

17 Since the coefficients of ds2 (estimated productivity level for industry) and ds3 (estimated productivity level for services) are positive, while the constant term (estimated productivity level for agriculture) of Model 3 is negative. 
using only data on agriculture, indicate a higher growth rate in the period 2000-2012, but the results point in the same direction as ours.

Table 1 Frontier Results

\begin{tabular}{|c|c|c|c|}
\hline & Model 1 & Model 2 & Model 3 \\
\hline $\log (\mathrm{L})$ & $* * * 0.518$ & $* * * 0.532$ & ***0.583 \\
\hline $\log (K)$ & $* * * 0.382$ & $* * * 0.420$ & ${ }^{* * *} 0.428$ \\
\hline ds $2 * \log (K)$ & $* * * 0.185$ & $* * * 0.133$ & $* * 0.089$ \\
\hline ds $3 * \log (K)$ & $* * * 0.263$ & $* * * 0.230$ & $* * 0.240$ \\
\hline Trend & ${ }^{*} 0.008$ & $* * * 0.014$ & $* * 0.013$ \\
\hline ds2 & $* * * 3.645$ & $* * * 4.334$ & $* * * 2.144$ \\
\hline ds3 & $* * * 5.105$ & $* * * 5.209$ & $* * * 4.148$ \\
\hline ts2 & 0.009 & ${ }^{*}-0.006$ & -0.003 \\
\hline ts3 & $* * *-0.017$ & $* * *-0.029$ & $* * *-0.029$ \\
\hline $\mathrm{W} * \log (\mathrm{L})$ & & 0.047 & ${ }^{* *}-0.108$ \\
\hline $\mathrm{W} * \log (\mathrm{K})$ & & 0.032 & ${ }^{*} 0.085$ \\
\hline$W^{*} \log (L) * d s 2$ & & & $* * * 0.219$ \\
\hline$W^{*} \log (K)^{*} \mathrm{ds} 2$ & & & -0.025 \\
\hline $\mathrm{W}^{*} \log (\mathrm{L}) * \mathrm{ds} 3$ & & & ${ }^{*} 0.115$ \\
\hline $\mathrm{W}^{*} \log (\mathrm{K})^{*} \mathrm{ds} 3$ & & & -0.056 \\
\hline Regional Fixed Ef. & No & Yes & Yes \\
\hline Constant & $* * *-1.695$ & $* * *-3.173$ & $* * *-2.129$ \\
\hline Num. Int. & 14 & 12 & 10 \\
\hline Log-likelihood & -587.06 & -271.75 & -253.83 \\
\hline Lambda & 0.008 & $* * * 15.6$ & $* * * 10.6$ \\
\hline \multicolumn{4}{|l|}{ Moran's I p-value } \\
\hline Agriculture & ${ }^{* * *} 0.008$ & 0.144 & 0.300 \\
\hline Industry & 0.207 & 0.352 & 0.446 \\
\hline Service & 0.967 & 0.153 & 0.128 \\
\hline
\end{tabular}

${ }^{*},{ }^{* *}$ and ${ }^{* * *}$ significant at $10 \%, 5 \%$ and $1 \%$, respectively.

Source: Elaborated by the authors.

Industry is growing at a similar pace (the difference is not significant, although negative), which replicates the results of Barbosa et al. (2010). Britto et al. (2015), estimating partial productivity (VA/L) only for industry, found that productivity in 2011 was $6.1 \%$ lower than in 2003 in that sector. Again, the conclusions are the same as in our case. Galeano and Feijó 
(2013) indicate declining productivity in manufacturing, especially in lowtech sectors, but their period of analysis is 1996-2007.

Productivity in services declined at $1.6 \%$ per year, which is compatible with the findings of Arbache (2015) and Jacinto and Ribeiro (2015).

Thus, our national results, which are based on regional data, are consistent with the results obtained in studies developed with national data, giving us confidence to proceed with the regional analysis.

\subsection{Regional}

\subsubsection{Efficiency Levels}

The model produces efficiency level indicators for each state, by year and by sector. Table 2 presents the ranking of states in terms of the average of efficiency in the whole period. The continuous horizontal line positions the states in terms of the national average; the dotted lines indicate the top, middle and lower thirds. The sectoral average is reported at the bottom of the table.

These estimates provide a rich framework of regional productive efficiency. It can be seen that the top tier of efficiency in agriculture includes states in the core of agricultural production in the country, mostly in the extended savannah area in the Center-West (MT, MS, GO) and North regions (TO, AC, AP, PA), which also involves some areas of the Northeast region (MA). The highest efficiency level, however, occurs in $M G$, in the Southeast region. The top performer state in Industry is AM, in the North. It hosts a very active free import zone, congregating the world top producers of electronics, pharmaceuticals and motorbikes, with state-of-the-art plants. Traditional industrial states of the Southeast (SP, RJ) and South (RS, $\mathrm{PR}$ ) regions belong to the upper third, as well as the oil-related states of BA and SE. States which excel in agriculture belong to the lower tier in industry. The situation in services is more heterogeneous. The top performer in these activities is the nation's capital (Brasilia - DF), which is the poorest performer in agriculture and is in the lower third in industry. The top performers in industry are typically in the middle tier in services, and the top performers in agriculture are in the lower third. 
Table 2 Estimated Efficiency Levels (average 2000-2014)

\begin{tabular}{|c|c|c|c|c|c|c|c|c|}
\hline \multirow[t]{2}{*}{ Rank } & \multicolumn{2}{|r|}{ Agriculture } & \multicolumn{2}{|r|}{ Industry } & \multicolumn{2}{|r|}{ Services } & \multicolumn{2}{|r|}{ Aggregate } \\
\hline & State & Efficiency & State & Efficiency & State & Efficiency & State & Efficiency \\
\hline 1 & $M G$ & 0,880 & AM & 0,899 & DF & 0,917 & DF & 0,899 \\
\hline 2 & MT & 0,875 & RS & 0,892 & SC & 0,915 & RJ & 0,889 \\
\hline 3 & TO & 0,869 & BA & 0,889 & PB & 0,912 & $\mathrm{SP}$ & 0,852 \\
\hline 4 & MA & 0,850 & $\mathrm{SP}$ & 0,867 & RN & 0,906 & PB & 0,848 \\
\hline 5 & $A C$ & 0,847 & RJ & 0,860 & RJ & 0,900 & PE & 0,845 \\
\hline 6 & GO & 0,844 & PR & 0,858 & PE & 0,897 & CE & 0,843 \\
\hline 7 & AP & 0,828 & $\mathrm{PI}$ & 0,842 & $\mathrm{CE}$ & 0,893 & RS & 0,838 \\
\hline 8 & MS & 0,798 & CE & 0,755 & $A L$ & 0,892 & RN & 0,837 \\
\hline 9 & PA & 0,728 & SE & 0,755 & ES & 0,888 & PR & 0,817 \\
\hline 10 & PR & 0,727 & RN & 0,739 & RS & 0,875 & $\mathrm{AL}$ & 0,815 \\
\hline 11 & ES & 0,723 & PE & 0,723 & RR & 0,859 & $\mathrm{RR}$ & 0,813 \\
\hline 12 & RO & 0,704 & PB & 0,698 & $\mathrm{SP}$ & 0,850 & SC & 0,806 \\
\hline 13 & $S P$ & 0,674 & $M G$ & 0,691 & SE & 0,840 & ES & 0,795 \\
\hline 14 & RR & 0,670 & RO & 0,688 & PR & 0,816 & SE & 0,783 \\
\hline 15 & PB & 0,644 & $\mathrm{AL}$ & 0,676 & $\mathrm{PI}$ & 0,810 & $\mathrm{PI}$ & 0,764 \\
\hline 16 & CE & 0,601 & ES & 0,662 & MA & 0,698 & MA & 0,717 \\
\hline 17 & $\mathrm{AL}$ & 0,586 & SC & 0,659 & PA & 0,693 & MS & 0,704 \\
\hline 18 & SC & 0,575 & TO & 0,656 & MS & 0,679 & $M G$ & 0,692 \\
\hline 19 & PE & 0,559 & DF & 0,638 & $M G$ & 0,654 & TO & 0,674 \\
\hline 20 & RS & 0,531 & MS & 0,616 & TO & 0,557 & PA & 0,653 \\
\hline 21 & $\mathrm{RN}$ & 0,481 & AP & 0,598 & $\mathrm{AP}$ & 0,476 & MT & 0,587 \\
\hline 22 & RJ & 0,456 & MT & 0,565 & GO & 0,475 & $A C$ & 0,565 \\
\hline 23 & AM & 0,455 & PA & 0,556 & BA & 0,470 & GO & 0,561 \\
\hline 24 & $\mathrm{PI}$ & 0,433 & GO & 0,549 & $\mathrm{AC}$ & 0,432 & $\mathrm{AM}$ & 0,559 \\
\hline 25 & BA & 0,389 & MA & 0,516 & RO & 0,424 & BA & 0,555 \\
\hline 26 & SE & 0,337 & $\mathrm{RR}$ & 0,486 & MT & 0,382 & RO & 0,545 \\
\hline 27 & DF & 0,264 & $A C$ & 0,358 & AM & 0,241 & AP & 0,513 \\
\hline Average & & 0,642 & & 0,692 & & 0,717 & & 0,732 \\
\hline
\end{tabular}

Source: Elaborated by the authors.

These sectoral levels of efficiency were aggregated for each state, using the sector's participation in the state value added as weights. Thus, in order to excel at the aggregate level, a state must show high efficiency in its important economic sectors. The final aggregate efficiency ranking 
results are displayed in Figure 2. The top performer is DF, due to its top position in services, its most relevant activity. SP and RJ, which constitute the manufacturing core of the country's economy, come next. Other traditional industrialized states from the South are also in this group (RS, PR). Good performance in services granted four states from the poor Northeast region $(\mathrm{PB}, \mathrm{PE}, \mathrm{CE}, \mathrm{RN})$ a position in the upper tier of aggregated efficiency.

\section{Figure 2 Aggregate Estimates of Regional Efficiency Levels}

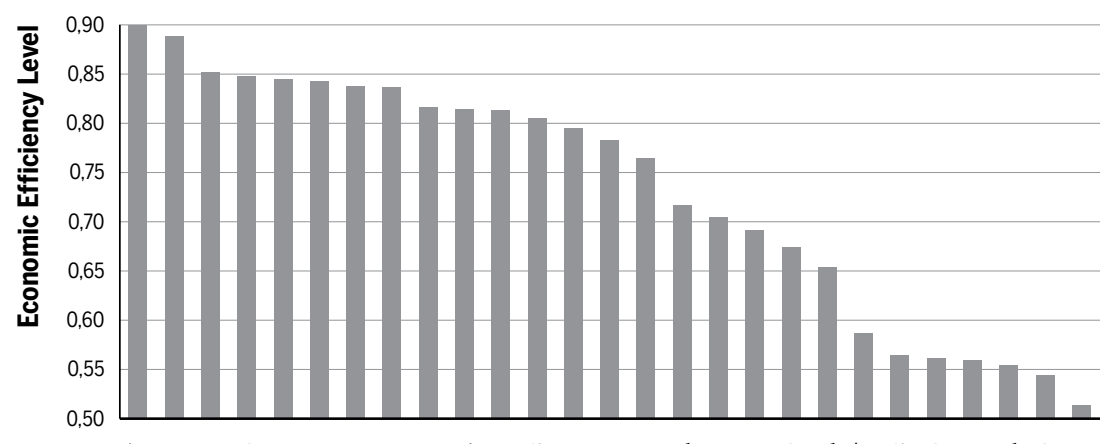

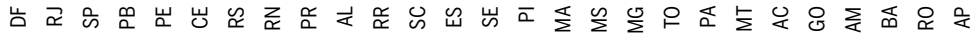

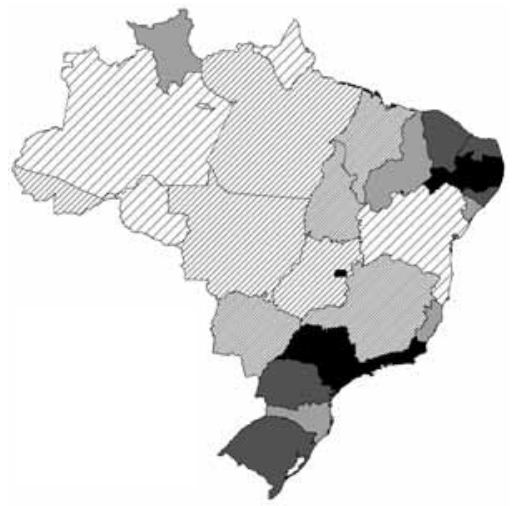

Average Efficiency Level

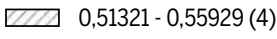

$0,55930-0,66727(4)$

$\square 0,66728-0,73210(4)$

$\square 0,73211-0,81420(5)$

$\square 0,81421-0,84407(5)$

0,84408-0,89944(5)

Horizontal line represents the national average.

Source: Elaborated by the authors.

\subsubsection{Efficiency Growth}

The model provides estimates of average efficiency growth rates for each state and sector in the period. The results are presented in Table 3. 
The fast-growers in agricultural efficiency include states in the CenterWest and North regions (AC, AM, RO, MT and MA in the savannah part of the Northeast), where this activity leads the state's economies, and some states in the Southeast (SP) and South (PR, RS). The important states in industrial production do not show high efficiency growth, which is observed in non-industrialized states (with the exception of $M G$ ). Services, again, present a distinct situation, with a mix of rich and poor states in the top tier.

The results allow us important considerations. For decades, the Northeast region experienced low performance indicators, while the Southeast led the high performance of the country. The numbers indicate that the Northeast continues to perform poorly in the period as a whole, but some states from Center-West and North are growing in efficiency. All the states in the Center-West and Southeast, with the exception of Rio de Janeiro, exhibit above-average growth. Only two states in the Northeast (BA and $\mathrm{AL}$ ) are in that situation (a petrochemical complex in BA and an ethanol and sugar complex in AL). Despite the high level of efficiency in services, states in that area have lost efficiency through time.

The aggregate rates presented in Table 3 are the weighted average of the sectoral rates, using the sectoral participation in the state's value added as weights. The top five growth rates are awarded to states which do not belong to the main economic core of the country, in spatial terms. States in this area come after, with growth rates much smaller than that of the first group. At the other end of the distribution, only states in the Northeast and North regions belong to the group with low growth rates.

Few states actually have rates above the national average, and these are concentrated in the southern regions. Only nine states present positive efficiency growth in all sectors (RO, AC, BA, RJ, PR, RS, MT, MS and DF). $\mathrm{PA}$ is the only with negative rates in all sectors.

The strong positive performance of agriculture in AM was not enough to counterbalance the negative rates of industry and services. The same happens to $\mathrm{AP}, \mathrm{MA}$ and $\mathrm{SE}$, and, in the case of high growth rates in industry, with PI, CE and PB. Services were responsible for the negative efficiency growth of TO and RN. On the positive side, services, for ES, and industry, for SC, were the sectors that accounted for the aggregate positive growth of these states. In SP, BA and RS, the above-average aggregate growth rates are led by the performance of agriculture and services. In the 
poor Northeast region, poor performance is observed in all sectors, but typically agriculture shows the worst performance in this region, followed by services. Figure 3 shows the rank of the growth rates of aggregate efficiency for the states.

Table 3 Efficiency Annual Growth Rates (2000-2014)

\begin{tabular}{|c|c|c|c|c|c|c|c|c|}
\hline \multirow[t]{2}{*}{ Rank } & \multicolumn{2}{|r|}{ Agriculture } & \multicolumn{2}{|r|}{ Industry } & \multicolumn{2}{|r|}{ Services } & \multicolumn{2}{|r|}{ Aggregate } \\
\hline & State & Efficiency & State & Efficiency & State & Efficiency & State & Efficiency \\
\hline 1 & SP & 4,49 & MT & 6,54 & $\mathrm{RR}$ & 2,61 & $A C$ & 3,41 \\
\hline 2 & $A C$ & 3,83 & RO & 6,46 & RO & 2,27 & RO & 3,21 \\
\hline 3 & AM & 3,39 & $A C$ & 4,04 & $A C$ & 2,13 & MT & 2,23 \\
\hline 4 & RO & 3,02 & GO & 3,89 & ES & 1,73 & $\mathrm{RR}$ & 1,44 \\
\hline 5 & PR & 3,01 & MS & 3,65 & MT & 1,61 & MS & 1,23 \\
\hline 6 & RN & 2,52 & PE & 3,14 & MS & 1,32 & DF & 0,96 \\
\hline 7 & MA & 1,92 & $M G$ & 1,66 & SP & 1,24 & SP & 0,90 \\
\hline 8 & RS & 1,92 & PB & 1,58 & MG & 1,18 & MG & 0,90 \\
\hline 9 & MT & 1,9 & RN & 1,48 & BA & 0,98 & PR & 0,869 \\
\hline 10 & DF & 1,82 & $\mathrm{CE}$ & 1,44 & DF & 0,94 & GO & 0,64 \\
\hline 11 & GO & 1,80 & $\mathrm{RR}$ & 1,22 & $A L$ & 0,83 & ES & 0,61 \\
\hline 12 & TO & 1,50 & SC & 0,95 & PR & 0,62 & $\mathrm{AL}$ & 0,55 \\
\hline 13 & AP & 0,66 & DF & 0,93 & RS & 0,47 & BA & 0,43 \\
\hline 14 & BA & 0,62 & RJ & 0,80 & RJ & 0,04 & RS & 0,34 \\
\hline 15 & SE & 0,61 & PI & 0,77 & PB & $-0,33$ & RJ & 0,14 \\
\hline 16 & RJ & 0,37 & PR & 0,72 & SE & $-0,34$ & SC & 0,00 \\
\hline 17 & MS & 0,17 & TO & 0,67 & SC & $-0,45$ & PE & 0,00 \\
\hline 18 & $M G$ & $-0,76$ & $\mathrm{AL}$ & 0,38 & $\mathrm{PE}$ & $-0,64$ & PB & $-0,019$ \\
\hline 19 & ES & $-1,19$ & BA & 0,07 & MA & $-0,70$ & MA & $-0,24$ \\
\hline 20 & $A L$ & $-1,70$ & RS & 0,05 & CE & $-0,77$ & RN & $-0,28$ \\
\hline 21 & PE & $-2,38$ & AM & $-0,11$ & RN & $-0,83$ & CE & $-0,40$ \\
\hline 22 & PB & $-2,80$ & SP & $-0,27$ & $\mathrm{PI}$ & $-0,90$ & SE & $-0,44$ \\
\hline 23 & $\mathrm{CE}$ & $-3,02$ & ES & $-0,41$ & GO & $-0,95$ & TO & $-0,45$ \\
\hline 24 & SC & $-3,14$ & SE & $-0,96$ & AM & $-1,77$ & $\mathrm{PI}$ & $-0,57$ \\
\hline 25 & $\mathrm{RR}$ & $-4,23$ & AP & $-1,78$ & TO & $-1,83$ & AM & $-0,89$ \\
\hline 26 & PA & $-4,64$ & PA & $-2,81$ & PA & $-2,06$ & PA & $-2,72$ \\
\hline 27 & $\mathrm{PI}$ & $-4,73$ & MA & $-4,14$ & AP & $-3,07$ & AP & $-2,72$ \\
\hline Averag & & 0,18 & & 1,11 & & 0,12 & & 0,34 \\
\hline
\end{tabular}

Source: Elaborated by the authors. 
Figure 3 Aggregate Estimates of Regional Efficiency Growth Rates (\% per year)
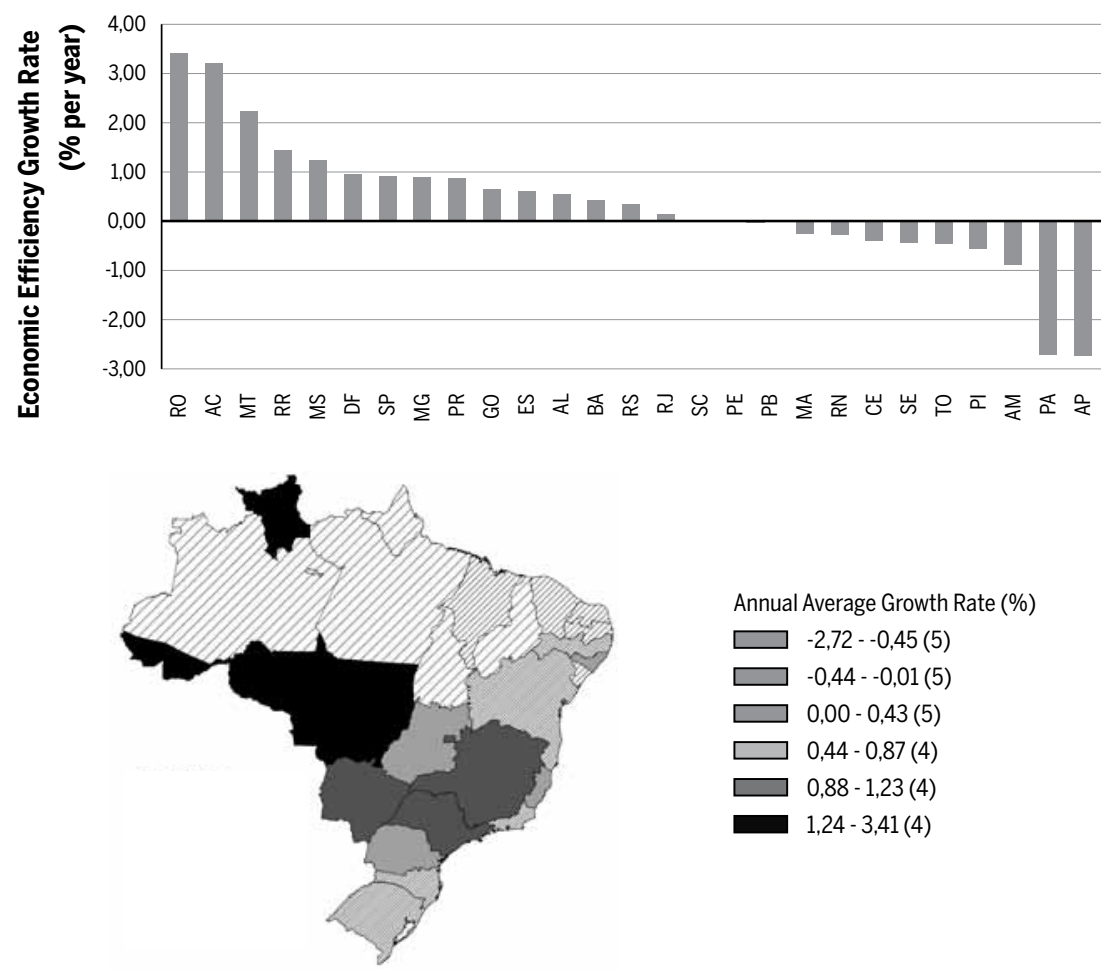

Annual Average Growth Rate (\%)

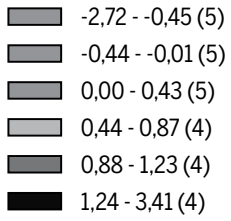

Source: Elaborated by the authors.

Again, a comparison of these results with those produced by other authors is plagued by the difficulties pointed out earlier. Gasques et al. (2013) estimated TFP in agriculture in the period 2000-2012 for some states, using labor, land and capital as inputs. They found that MG, BA, GO, PR and MT presented above-average TFP growth rates. These states are in the above-average group also in our study, but only PR and MT are in our topgrowing group. In industry, Britto et al. (2015) considered the period 19962011, using a partial productivity indicator (VA/L). They found negative growth rates for all macro regions, but the Center-West and the Northeast presented better performance. AM and PA are in the lower tier of our results, a result in line with their finding that the North macro region had the most intensive decrease in productivity. The states of MT, GO and MS are in our upper tier, which is compatible with their result for the Center- 
West macro region. Their conclusion that the Northeast macro region had better-than-average performance is not contradicted by our finding that $\mathrm{PE}, \mathrm{PB}, \mathrm{RN}$ and $\mathrm{CE}$ are in the upper tier of productivity growth. In spite of the differences in methodology and periodicity, our regional results, in general, are in line with the available evidence.

\section{Regional efficiency convergence}

As mentioned before, some efficiency results are compatible with the regional disparity levels observed in the country in many aspects, as GDP per capita, poverty, education, as well as in regional concentration. Changing this situation requires that low performing regions improve at a faster rate than high performing regions. The presence of convergence indicates that differences in productivity levels across states will reduce over time. This could happen both at a national upper or lower level, depending on the national trend. If productivity is growing at the national level, as is the case of agriculture, the resulting equality will occur at a higher level of productivity. In the case of services, which show declining productivity, equality would happen at a lower efficiency level.

In order to analyze signs of convergence in each sector, we have correlated the initial (average of 2000-2002) levels of efficiency in each state with the estimated efficiency growth rates, as presented in Figure 4 to 7.

The results for agriculture are in Figure 4. The six states with high initial efficiency levels and positive growth rates belong to the North and CenterWest regions. Two northeastern states, PI and PE, are in the third quadrant, exhibiting low initial efficiency levels and negative growth rates. While SE, $\mathrm{BA}$ and $\mathrm{RN}$, in the same region, exhibit positive growth rates, the Southeastern and Southern states of PR, DF, RS, RJ and SP, show below-average efficiency levels and positive growth rates. Thus, the situation in agriculture shows slight signs of convergence. A simple regression of the growth rates on the initial levels (2000-2002 average) indicates that convergence cannot be ruled out at the $5 \%$ significance level. As can be seen in Figure 4 , the larger states in terms of production are in the first quadrant, meaning high efficiency levels and high growth rates. This indicates that the convergence process will result in higher efficiency rates in general at the national level. 
Figure 4 Regional Efficiency Levels and Growth Rates in Agriculture

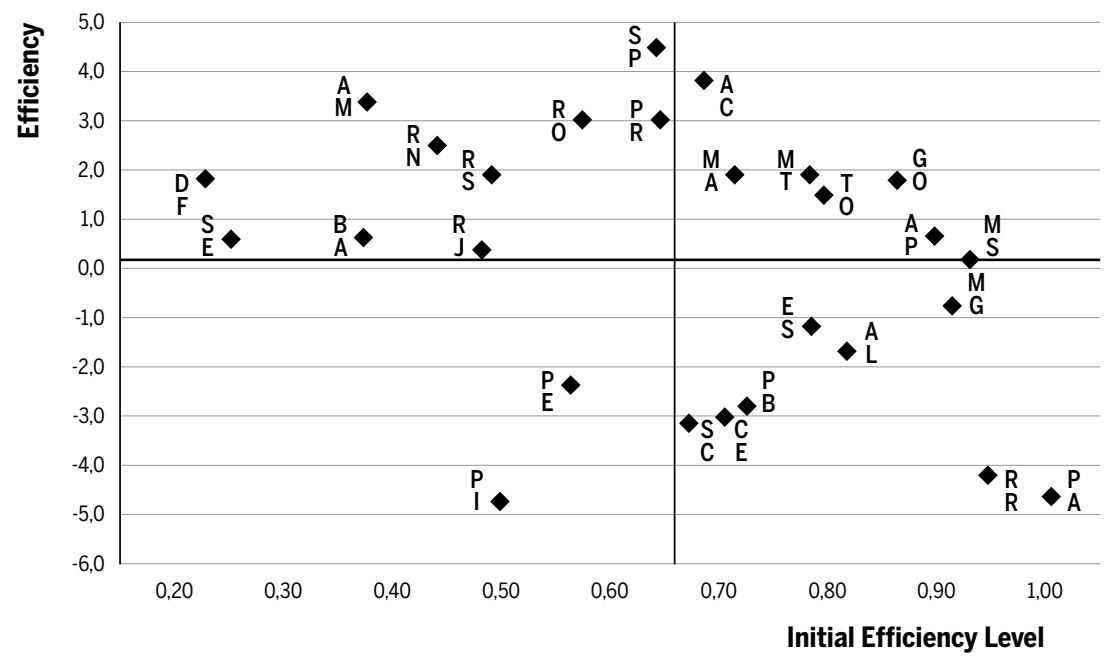

Source: Elaborated by the authors.

The situation with industry (Figure 5) is closer to convergence, since states with low initial efficiency levels tend to present higher growth rates, and states at the other extreme, negative rates. AM, home of the free import zone, was the most efficient in industry, and depicted a negative growth rate. In the same region, $\mathrm{AP}$ also presented a negative growth rate. The upper left-hand quadrant receives northern ( $\mathrm{RO}, \mathrm{AC}, \mathrm{RR})$ and center-western states (MT, MS, GO), which, together with the northeastern state of RN and southeastern state of MG, show below-average initial levels and positive growth rates. The economically important states of the rich Southeast (RJ, SP) and South (RS, PR, SC) show above-average initial levels and negative growth rates. A simple regression of the growth rates on the initial levels (2000-2002 average) indicates that, at the 1\% significance level, convergence cannot be ruled out. As can be seen in Figure 5, the most representative states in terms of industrial production are in the fourth quadrant, meaning high efficiency levels and negative growth rates. Thus, the ending result of the convergence process comes with a decrease in the national efficiency level. 
Figure 5 Regional Efficiency Levels and Growth Rates in Industry

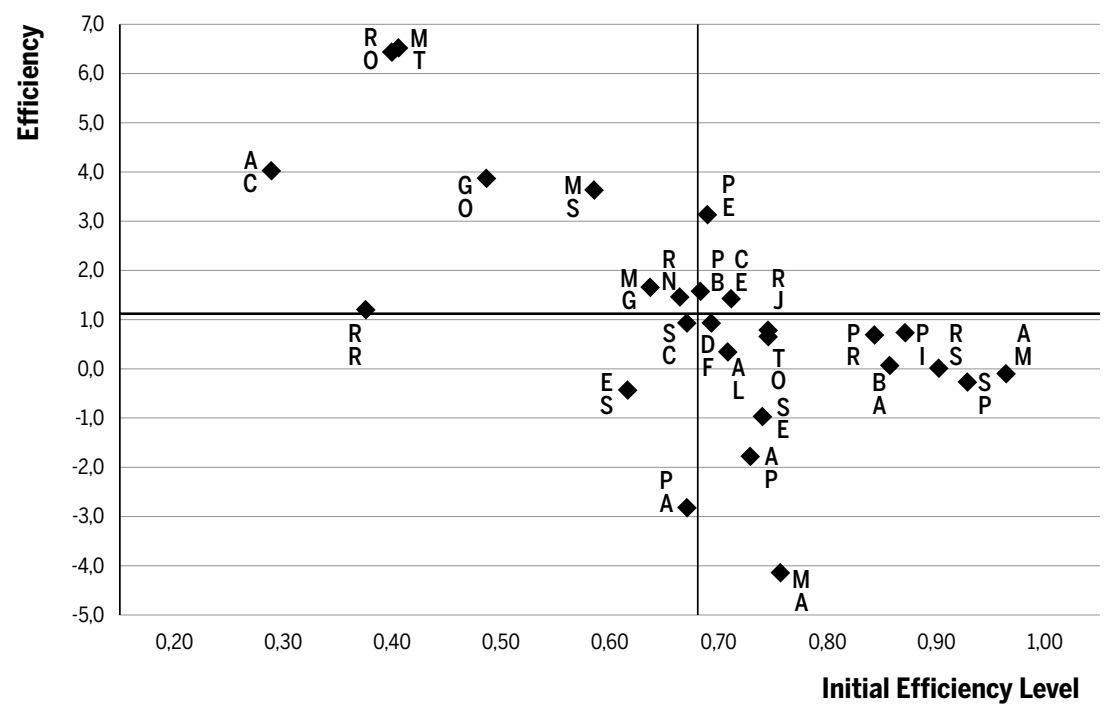

Source: Elaborated by the authors.

The heterogeneous service sector is more complex to analyze (Figure 6). Of the 17 states with above-average initial efficiency levels, seven presented positive, and ten negative growth rates. The same proportion (60/40) situation is repeated with the below-average states. All the four negative cases of low levels and negative rates belong to the northern region, and $\mathrm{GO}$, in the Center-West, but some positive cases are also from those regions (RO, AC, MT, MS). A simple regression of the growth rates on the initial levels (2000-2002 average) did not indicate signs of convergence.

Considering the aggregate of all sectors, displayed in Figure 7, it seems that some convergence is taking place. The northern states of $\mathrm{RO}, \mathrm{AC}$ and MT display low average initial efficiency levels, but experienced the highest efficiency growth rates. However, AP and AM, in the same region, with similar average initial efficiency, presented negative efficiency growth rates. States in the right-hand side of the horizontal axis display above-average initial efficiency levels. In this case, we observe more states presenting negative growth rates. Seven out of the nine northeastern states showed negative efficiency growth rates. A simple regression of the growth rates on the initial levels (2000-2002 average) indicates that convergence cannot be ruled out at the $10 \%$ significance level. These results 
are compatible with Azzoni and Silveira-Neto (2005), who, in spite of the difference in period of analysis, concluded that agriculture and services acted in favor of divergence, while industry (especially manufacturing) favored the convergence.

Figure 6 Regional Efficiency Levels and Growth Rates in Services

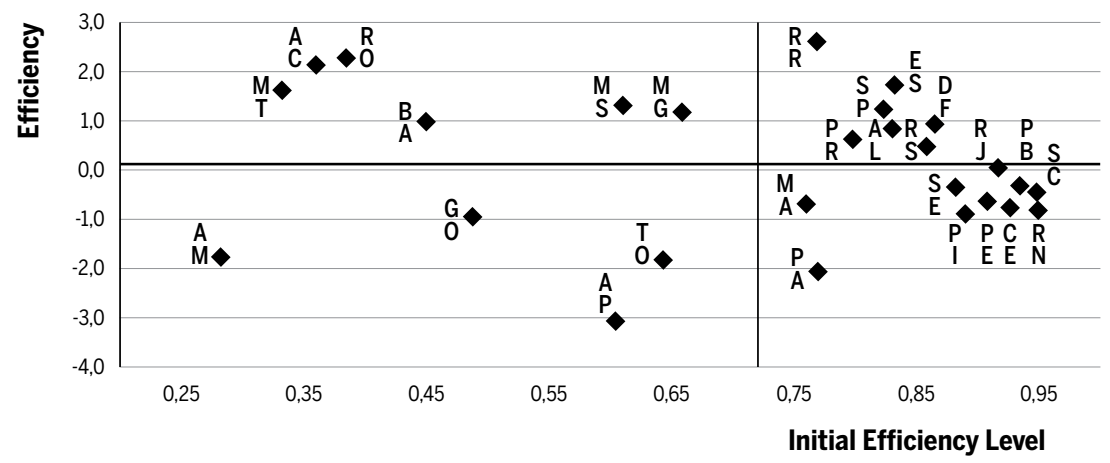

Source: Elaborated by the authors.

Figure 7 Regional Efficiency Levels and Growth Rates - All Sectors

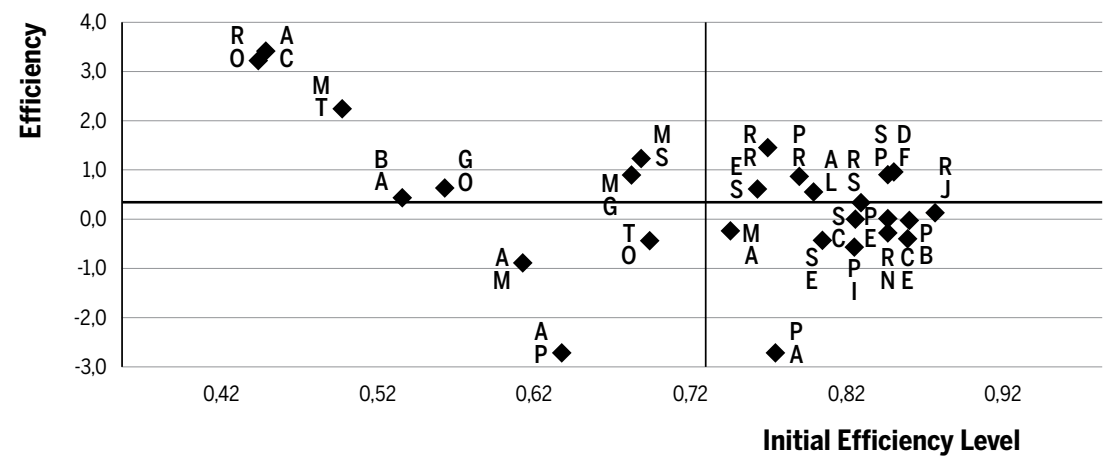

Source: Elaborated by the authors.

\section{Conclusions}

We have tackled the question of regional inequalities in Brazil from the fundamental point of view of the evolution of regional competitiveness. We have estimated efficiency levels and growth for the states in recent 
years, in order to gather information on their relative positions and the evolution of productivity, as a sign of potential future competitiveness. We use state-level data for the first time in this type of estimative procedure. Our results show that agriculture is leading the growth in efficiency at the national level, followed by industry, probably due to the extractive activities. The tertiary sector experiences a decrease in productivity. These aggregate results are compatible with the available estimates based on national data. Thus, our approach provides regional estimates that are compatible with the established national results.

Other contributions of this study relate to the simultaneous estimation of efficiency for the three main sectors of activity. Other authors have estimated similar measures for individual sectors, ignoring the interaction between sectors of activity. By dealing with a period already into the XXI century, we provide evidence on the possible effects of important changes in the national economy. We use Stochastic Frontiers to estimate the efficiency levels, introducing spatial effects in the estimations, which is new in the literature of both topics.

The estimated productivity levels indicate that the most productive states are in the richer part of the country, although some exceptions appear in the Center-West and North, mostly related to agriculture. The estimated efficiency growth rates reveal the possibility of changes in the inequality scenario, with some signs of convergence, especially in industry, which may be changing the observed disparity in the aggregate of the economic activities.

Some exceptional cases of success outside the traditional economic center of the country are, in a way, related to government initiatives. These are the cases of the free-trade zone in the North, the petrochemical complex in Bahia, but the most impressive case is the performance of the agricultural states of the Center-West and some border states in the North (RO, AC) and Northeast (MA, RN, BA). The technological development led by Embrapa, the government-owned research institution in agriculture, has created the conditions for states in that region to go from the low productivity agriculture in the past into a state-of-the-art and highly competitive modern activity. More recently, social programs targeting poor families have created a growing demand for wage goods in poor areas, leading to some movement of part of the production of this sort of goods in the vicinity of the new consumption centers. New private investments supported by government programs in the Northeast reinforced this movement, such 
as automobile assembling plants in Bahia and Recife, the naval industry and a massive petrochemical complex in Recife. Since these factors exerted their influence mostly in the $21{ }^{\text {st }}$ Century, their consequences might only be starting to appear in the most recent trends.

The recent changes are good news, in terms of the excessive concentration of production in the country, as well as in terms of regional inequality indicators. But the changes are too soft to produce relevant changes in the highly concentrated situation observed in the country. Even after two decades of a stabilized and more open economy, the competitiveness situation still, on average, favors the traditional economic core. In spite of the recent progress, the competitive position of peripheral regions is limited by the lack of infrastructure, especially in comparison to the core region (Schettini; Azzoni, 2015). The maintenance of the scenario of high demand for wage goods, propelled by social programs and the implementation of large scale projects, could increase the stress on the limited infrastructure present outside the core region. Surpassing this barrier is a challenge to government, which is locked into a tight budgetary situation. Creative ways of financing infrastructure expansion will have to be designed and implemented, with the necessary participation of the private sector. But the positively changing scenario might make investments in infrastructure in the peripheral regions more attractive to private investors, provided a clean and safe regulatory apparatus is established. Maybe the challenge lies in providing such apparatus in a sound way.

\section{References}

AIGNER, D.J.; LOVELL, C.A.K; SCHMIDT, P. Formulation and Estimation of Stochastic Frontier Production Function Models. Journal of Econometrics, v. 6, p. 21-37, 1977.

ANSELIN, L. Spatial Econometrics: Methods and Models. Netherlands: Springer, 1988.

ARBACHE, J. Produtividade no Setor de Serviços. In: DE NEGRI, F.; CAVALCANTE, L.R. (Ed.). Produtividade no Brasil: Desempenho e Determinantes - V2. Brasília: IPEA, 2015.

AZZONI, C.R.; HADDAD, E.A. Regional Disparities. In: BAER, W.; AZZONI, C.R.; AMMAN, E. (Ed.). The Oxford Handbook of the Brazilian Economy. USA: Oxford University Press, 2018.

AZZONI, C.R.; SILVEIRA-NETO, R.M. Decomposing Regional Growth: Labor Force Participation Rates, Structural Changes, and Sectoral Factor Reallocation. The Annals of Regional Science, v. 39, n. 2, p. 221-239, 2005. 
BAER, W. The Brazilian Economy: Growth and Development. USA: Lynne Rienner Publishers, $6^{\text {th }}$ Edition, 2007.

BALK, B.M. Scale Efficiency and Productivity Change. Journal of Productivity Analysis, v. 15, n. 3, p. 159-183, 2001.

BARBOSA FILHO, F.H.; PESSÔA, S.A.; VELOSO, F.A. Evolução da Produtividade Total dos Fatores na Economia Brasileira com Ênfase no Capital Humano - 1992-2007. Revista Brasileira de Economia, v. 64, n. 2, p. 91-113, 2010.

BARRETO, F.A.F.D.; NOGUEIRA, C.A.G.; ROSA, A.L.T. Crescimento e Capital Humano: Evidências Empíricas Recentes para o Brasil numa Perspectiva Regional. Texto para Discussão, Fortaleza, CAEN/UFC, 1999.

BONELLI, R. Growth and productivity in Brazilian industries: Impacts of Trade Orientation. Journal of Development Economics, v. 39, n. 1, p. 85-109, 1992.

BONELLI, R. Ensaios sobre política econômica e industrialização no Brasil. Rio de Janeiro: Senai-DN/DITEC/DPEA, 1996.

BONELLI, R. Produtividade e Armadilha do Lento Crescimento. In: DE NEGRI, F; CAVALCANTE, L.R. (Ed.). Produtividade no Brasil: Desempenho e Determinantes - V1. Brasília: IPEA, 2014.

BONELLI, R.; FONSECA, R. Ganhos de Produtividade e de Eficiência: Novos Resultados para a Economia Brasileira. Pesquisa e Planejamento Econômico, v. 28, n. 2, p. 273-314, Aug. 1998.

BONELLI, R.; BACHA, E.L. Crescimento brasileiro revisitado. In: VELOSO, F. et al. (ed.). Desenvolvimento Econômico: uma Perspectiva Brasileira. Rio de Janeiro: Elsevier, 2013.

BONELLI, R.; VELOSO, F. Rio de Janeiro: Crescimento Econômico e Mudança Estrutural. In: PINHEIRO, A. C.; VELOSO, F. (Ed.). Rio de Janeiro: um estado em transição. Rio de Janeiro: Editora FGV, 2012.

BRAGAGNOLO, C.; SPOLADOR, H.F.S.; BARROS, G.S.C. Regional Brazilian Agriculture TFP Analysis: A Stochastic Frontier Analysis Approach. EconomiA, Brasília, v. 11, n. 4, p. 217-242, 2010.

BRIGATTE, H.; TEIXEIRA, E.C. Determinantes de longo prazo do produto e da produtividade total dos fatores da agropecuária brasileira no período 1974-2005. Revista de Economia e Sociologia Rural, Piracicaba, SP, v. 49, n. 04, p. 815-836, 2012.

BRITTO, G.; AMARAL, P.V.; ALENCAR, D.A. Produtividade industrial nas microrregiões brasileiras (1996-2011). In: DE NEGRI, F; CAVALCANTE, L.R. (Ed.). Produtividade no Brasil: Desempenho e Determinantes - V2. Brasília: IPEA, 2015.

CANGUSSU, R.C.; SALVATO, M.A.; NAKABASHI, L. Uma análise do capital humano sobre o nível de renda dos estados brasileiros: Mrw versus mincer. Estudos Econômicos, v. 1, n. 40, p. 153-183, 2010.

DE NEGRI, F; CAVALCANTE, L.R. Os dilemas e os desafios da produtividade no Brasil. In: DE NEGRI, F.; CAVALCANTE, L.R. (Ed.). Produtividade no Brasil: Desempenho e Determinantes - V1. Brasília: IPEA, 2014.

FÄRE, R.; GROSSKOPF, S.; LOVELL, C.A.K. Production frontiers. USA: Cambridge University Press, 1994. 
FARREL, M.G. The Measurement of Productive Efficiency. Journal of the Royal Statistical Society, v. 120 (Series A), n. 3, p. 253-281, 1957.

FEIJÓ, C.A.; CARVALHO, P.G.M. Uma Interpretação sobre a Evolução da Produtividade Industrial no Brasil nos Anos Noventa e as "Leis" de Kaldor. Nova Economia, v. 12, n. 2, p. $57-78,2002$.

FELEMA J.; RAIHER, A.P.; FERREIRA, C.R. Agropecuária Brasileira: Desempenho Regional e Determinantes de Produtividade. Revista de Economia e Sociologia Rural, Piracicaba, SP, v. 51, n. 3, p. 555-574, 2013.

FERREIRA, F.H.G.; LEITE, P.G.; LITCHFIELD, J.A. The Rise and Fall of Brazilian Inequality: 1981-2004. Working Paper 3867, Washington, D.C.: World Bank, 2006.

FERREIRA, P.C.; VELOSO, F. O Desenvolvimento Econômico Brasileiro no Pós-Guerra. In: VELOSO, F. et al. (Ed.). Desenvolvimento Econômico: uma Perspectiva Brasileira. Rio de Janeiro, Elsevier, 2013.

FIGUEREDO, L.; NORONHA, K.; ANDRADE, M. Os Impactos da Saúde Sobre o Crescimento Econômico na Década de 90: Uma Análise para os Estados Brasileiros. Texto para discussão 219, Cedeplar/UFMG, 2003.

FRANZESE, R.; HAYS, J. Spatial-Econometric Models of Cross-Sectional Interdependence in Political-Science Panel and Time-Series-Cross-Section Data. Political Analysis, v. 15, n. 2, p. 140-164, 2007.

GALEANO, E.A.V; FEIJÓ, C. A estagnação da produtividade do trabalho na indústria brasileira nos anos 1996-2007: análise nacional, regional e setorial. Nova Economia, v. 23, n. 1, p. 9-49, 2013.

GALEANO, E.A.V.; WANDERLEY, L.A. Um estudo sobre o comportamento da produtividade industrial do trabalho nas regiões do Brasil no período de 1996 a 2010. Revista Geografares, n. 15, p. 139-180, 2013.

GALLO, J.L.; DALL'ERBA, S. Spatial and Sectoral Productivity Convergence Between European Regions, 1975-2000. Papers in Regional Science, v. 87, n. 4, p. 505-525, 2008.

GASQUES, J.G.; CONCEIÇÃO, J.C.P.R. Transformações Estruturais da Agricultura e Produtividade Total de Fatores. Texto para Discussão N. 768, IPEA Brasília, 2000.

GASQUES, J.G.; BASTOS, E.T.; BACHI, M.R.P.; CONCEIÇÃO, J. Condicionantes da Produtividade da Agropecuária Brasileira. Texto para Discussão N. 1017, IPEA Brasília, p. 7-30, 2004a.

GASQUES, J.G.; REZENDE, G. C.; VERDE, C.M.V.; SALERNO, M.S., CONCEIÇÃO, J. C.P.R.; CARVALHO, J.C.S. Desempenho e crescimento do agronegócio no Brasil. Texto para Discussão N. 1009, IPEA Brasília, v. 1, p. 1-39, 2004 b.

GASQUES, J.G.; BASTOS, E.T.; VALDES, C.; BACCH, M.R.P. Produtividade da Agricultura Brasileira e os Efeitos de Algumas Políticas. Revista de Política Agrícola, n. 3, p. 83-92, 2012.

GASQUES, J.G.; BASTOS, E.T.; VALDES, C.; BACCHI, M. Produtividade e Crescimento: Algumas comparações. In: ALVES, E.R.A.; SOUZA, G.S.; GOMES, E.G. (Ed.). Contribuição da Embrapa para o Desenvolvimento da Agricultura no Brasil. Brasília: Embrapa. 2013.

GASQUES, J. G.; BASTOS, E.T.; VALDES C.; BACCHI, M. Produtividade da agricultura Resultados para o Brasil e estados selecionados. Revista de Política Agrícola, Ano XXIII, n. 3, 
p. 87-98, Jul/Ago/Set 2014.

GOMES, V.; PESSÔA, S.; VELOSO, F. Evolução da produtividade total dos fatores na economia brasileira: uma análise comparativa. Pesquisa e Planejamento Econômico, v. 33, n. 3, p. 389-434, 2003.

GONÇALVES, S.P.; NEVES, E.M. Inovação tecnológica, produtividade e preço ao consumidor de feijão no estado de São Paulo, 1970-2005. In: XLV CONGRESSO DA SOBER, Londrina: UEL, 2007.

GRAY, E.; JACKSON, T.; ZHAO, S. Agricultural Productivity: Concepts, Measurement and Factors Driving It - A Perspective From the ABARES Productivity Analyses. Australia: Australian Government Rural Industries Research and Development Corporation, n. 10/161, Mar. 2011.

GREENE, W. Fixed and Random Effects in Stochastic Frontier Models. Journal of Productivity Analysis, v. 23, n. 1, p. 7-32, 2004a.

GREENE, W. Distinguishing Between Heterogeneity and Inefficiency: Stochastic Frontier Analysis of 152 the World Health Organization's Panel Data on National Health Care Systems. Health Economics, v. 13, n. 10, p. 959-980, 2004 b.

IPEA. Produtividade no Brasil nos Anos 2000-2009: Análise das Contas Nacionais. Comunicados do Ipea, n. 133, 2012.

JACINTO, P.A.; RIBEIRO, E. P. Crescimento da Produtividade no Setor de Serviços da Indústria no Brasil: Dinâmica e Heterogeneidade. Economia Aplicada, v. 19, n. 3, p. 401-427, 2015.

JONDROW, J.; LOVELL, C.A.K.; MATEROV, I.S.; SCHMIDT P. On the Estimation of Technical Inefficiency in the Stochastic Frontier Production Function Model. Journal of Econometrics, v. 19, n. 2-3, p. 233-238, 1982.

KALDOR, N. The Case for Regional Policies, Scottish Journal of Political Economy, v. 17, n. 3, p. 337-348, 1970.

KLOTZ, S. Cross Sectional Dependence in Spatial Econometric Models. Germany: Lit Verlag Münster, 2004.

KUPFER, D. Trajetórias de Reestruturação da Indústria Brasileira Após a Abertura e a Estabilização: Temas para Debate. Boletim de Conjuntura, Rio de Janeiro, lE/UFRJ, v. 18, n. 2, 1998.

LABRUNIE, M.; SABOIA, J. A produtividade do trabalho do setor de serviços e a evolução recente do mercado de trabalho no Brasil. Texto para Discussão 026, Instituto de Economia, UFRJ, 2016.

LOVELL, C.A.K. Production frontiers and productive efficiency. In: FRIED, H.O (Ed.) The Measurement of Productive Efficiency: Techniques and Applications. United Kingdom: Oxford University Press, 1993

MARINHO, E.; CARVALHO, R.M. Comparações Inter-Regionais da Produtividade da Agricultura Brasileira - 1970-1995. Pesquisa e Planejamento Econômico, v. 34, n. 1, p. 57-92, 2004.

MCMILLAN, M.S.; RODRIK, D. Globalization, Structural Change and Productivity Growth. NBER Working Paper, n. 17143, 2011.

MEEUSEN, W.; BROECK, J.V.D. Efficiency Estimation from Cobb-Douglas Production Functions with Composed Error. International Economic Review, v. 18, n. 2, p. 435-444, 1977. 
MESSA, A. Determinantes Da Produtividade na indústria Brasileira. In: DE NEGRI, F.; CAVALCANTE, L.R. (Ed.). Produtividade no Brasil: Desempenho e Determinantes - V2. Brasília: IPEA, 2015.

MONASTERIO, L.; REIS, E. Mudanças na concentração espacial das ocupações nas atividades manufatureiras 1872-1920. Texto para Discussão N. 1361. Rio de Janeiro: Ipea, 2008.

NAKABASHI, L.; SALVATO, M.A. Human Capital Quality in the Brazilian States. Revista EconomiA, v. 8, n. 2, p. 211-229, 2007.

NORONHA, K.; FIGUEIREDO, L.; ANDRADE, M.V. Health and economic growth among the states of Brazil from 1991 to 2000. Revista Brasileira de Estudos Populacionais, v. 27, n. 2, p. 269-283, 2010.

NOGUEIRA, M.O.; INFANTE, R.; MUSSI, R. Produtividade do Trabalho e Heterogeneidade Estrutural no Brasil Contemporâneo In: DE NEGRI, F.; CAVALCANTE, L.R. (Ed.). Produtividade no Brasil: Desempenho e Determinantes - V1. Brasília: IPEA, 2014.

QUADROS, R.; FURTADO, A.; BERNARDES, R.C.; FRANCO, E. Padrões de inovação tecnológica na indústria paulista comparação com os países industrializados. São Paulo em Perspectiva, v. 13, n. 1-2, p. 53-66, 1999.

ROSSI JR., J.L.; FERREIRA, P.C. Evolução da produtividade industrial brasileira e abertura comercial. Texto para Discussão N. 651, Rio de Janeiro: IPEA, 1999.

SCHETTINI, D.; AZZONI, C. R. Diferenciais Regionais de Competitividade Industrial do Brasil no século 21. Economia, Brasília, v. 14, n. 1B, p. 361-387, 2013.

SCHETTINI, D.; AZZONI, C. R. Determinantes Regionais da Produtividade Industrial: o Papel da Infraestrutura. In: DE NEGRI, F.; CAVALCANTE, L.R. (Ed.). Produtividade no Brasil: Desempenho e Determinantes - V2. Brasília: IPEA, 2015.

SILVEIRA-NETO, R.M.; AZZONI, C.R. Non-Spatial Government Policies and Regional Income Inequality in Brazil. Regional Studies, v. 45, n. 4, p. 453-461, 2011.

SILVEIRA NETO, R.M.; AZZONI, C.R. Social Policy as Regional Policy: Market and Nonmarket Factors Determining Regional Inequality. Journal of Regional Science, v. 52, n.3, p. 433-450, 2012.

SOARES, S.; RIBAS, R.P.; SOARES, F.V. Focalização e Cobertura do Programa Bolsa-Família: Qual o Significado dos 11 Milhões de Famílias? Texto para Discussão N. 1396, IPEA, 2009.

SQUEFF G.C. Desindustrialização em Debate: Aspectos Teóricos e Alguns Fatos Estilizados da Economia Brasileira. Radar Tecnologia, Produção e Comércio Exterior. Diretoria de Estudos e Políticas Setoriais, n. 21, p. 7-17, 2012.

VICENTE, J.R.; ANEFALOS, L.C.; CASER, D.V. Produtividade Agrícola no Brasil, 1970-1995. Agricultura em São Paulo SP, v. 39, n. 2, p. 1-23, 2001.

VICENTE, J.R. Produtividade Total de Fatores e Eficiência no Setor de Lavouras da Agricultura Brasileira, Revista de Economia e Agronegócio, v. 9, n. 3, p. 303-324, 2011.

VIEIRA FILHO J.E.R.; CAMPOS, A.C.; FERREIRA, C.M.C. Abordagem Alternativa do Crescimento Agrícola: um Modelo de Dinâmica Evolucionária. Revista Brasileira de Inovação, Campinas, v. 4, n. 2, p. 425-476, 2005.

WARD, M.D.; GLEDTISCH, K.S. Spatial Regression Models. USA: Sage Publications, 2008. 
WEBBER, D.J.; HUDSON, J.; BODDY, M.; PLUMRIDGE, A. Regional Productivity Differentials in England: Explaining the Gap. Papers in Regional Science, v. 88, n. 3, p. 609-621, 2009.

\author{
About the authors \\ DanielaSchettini - danischettini@usp.br \\ Instituto de Relações Internacionais - Universidade de São Paulo. \\ CarlosRobertoAzzoni-cazzoni@usp.br \\ Faculdade de Economia, Administração e Contabilidade - Universidade de São Paulo.
}

\title{
About the article
}

Submission received on July 04, 2017. Approved for publication on February 07, 2018. 


\section{APPENDIX}

Table A1 States and Regions

\begin{tabular}{|c|c|c|c|c|}
\hline North (N) & Northeast (NE) & Southeast (SE) & South (S) & Center-West (CW) \\
\hline RO - Rondônia & MA - Maranhão & MG - Minas Gerais & PR - Paraná & MS - Mato Grosso \\
\hline AC-Acre & PI-Piauí & ES - Espírito Santo & SC - Santa Catarina & do Sul \\
\hline AM - Amazonas & CE - Ceará & RJ - Rio de Janeiro & RS - Rio Grande & MT - Mato Grosso \\
\hline RR - Roraima & RN - Rio Grande & SP-São Paulo & do Sul & G0 - Goiás \\
\hline PA - Pará & do Norte & & & DF - Distrito Federal \\
\hline AP-Amapá & PB - Paraíba & & & \\
\hline \multirow[t]{4}{*}{ TO - Tocantins } & PE - Pernambuco & & & \\
\hline & AL - Alagoas & & & \\
\hline & SE - Sergipe & & & \\
\hline & BA-Bahia & & & \\
\hline
\end{tabular}

Table A2 Descriptive Statistics

\begin{tabular}{|c|c|c|c|c|}
\hline & Annual Average & Std. Dev. & Minimum & Maximum \\
\hline \multicolumn{5}{|c|}{ Agriculture } \\
\hline \multirow[t]{2}{*}{ VA } & & & $21,560(\mathrm{AP}, 2003)$ & $3,646,652(\mathrm{MG}, 2011)$ \\
\hline & 801.734 & 850.174 & $21,560(\mathrm{AP}, 2003)$ & 3,646,652 (MG, 2011) \\
\hline $\mathrm{L}$ & 454.057 & 405.812 & 11,639 (AP, 2001) & $1,675,794$ (BA, 2009) \\
\hline K & 30.519 & 45.617 & $41(\mathrm{AP}, 2014)$ & 190,491 (RS, 2014) \\
\hline \multicolumn{5}{|c|}{ Industry } \\
\hline VA & 2.561 .871 & 4.858 .193 & $8,613(\mathrm{AC}, 2001)$ & $27,185,702(S P, 2008)$ \\
\hline L & 51.818 & 86.642 & $363(\mathrm{RR}, 2014)$ & 477,760 (SP, 2011) \\
\hline K & 173.415 & 280.251 & $745(\mathrm{AC}, 2000)$ & $1,546,169(\mathrm{SP}, 2008)$ \\
\hline \multicolumn{5}{|c|}{ Services } \\
\hline VA & 6.952 .270 & 13.600 .000 & $138,991(\mathrm{RR}, 2000)$ & $99,229,751$ (SP, 2014) \\
\hline $\mathrm{L}$ & 1.329 .757 & 1.870 .262 & 41,927 (RR, 2001) & $10,835,111$ (SP, 2014) \\
\hline K & 2.281 & 3.505 & $75(\mathrm{RR}, 2003)$ & 23,921 (SP, 2014) \\
\hline
\end{tabular}

The text in parentheses identifies the state and year of minimum and maximum values. 
Figure A1 Evolution of the main variables at the national level

\section{Value Added ( $Y$}

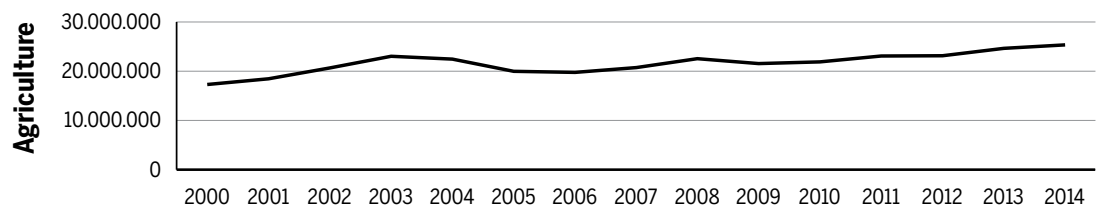

BRL of 2013

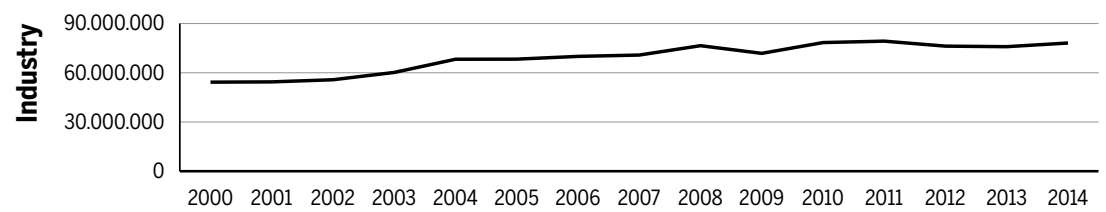

BRL of 2013

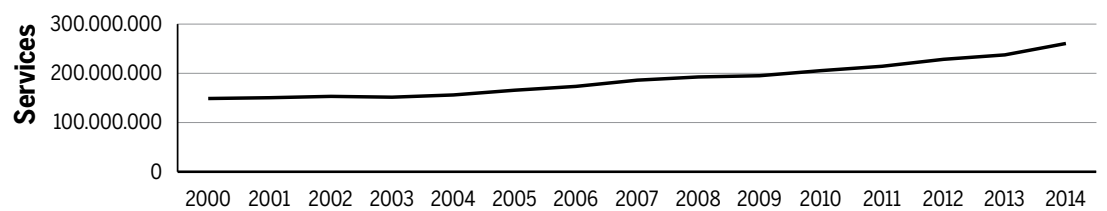

BRL of 2013 


\section{Labor (L)}

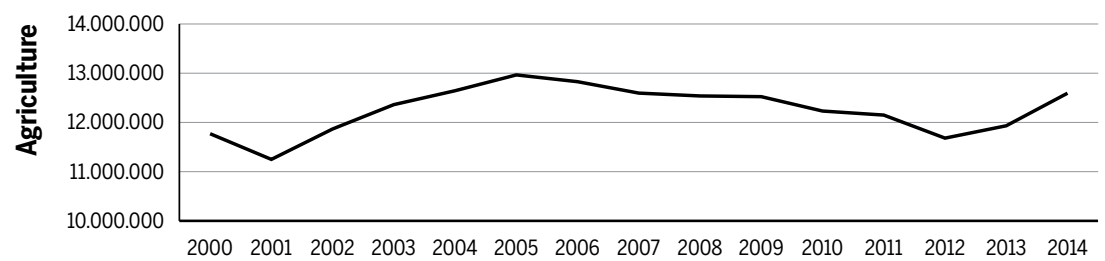

Number of employees

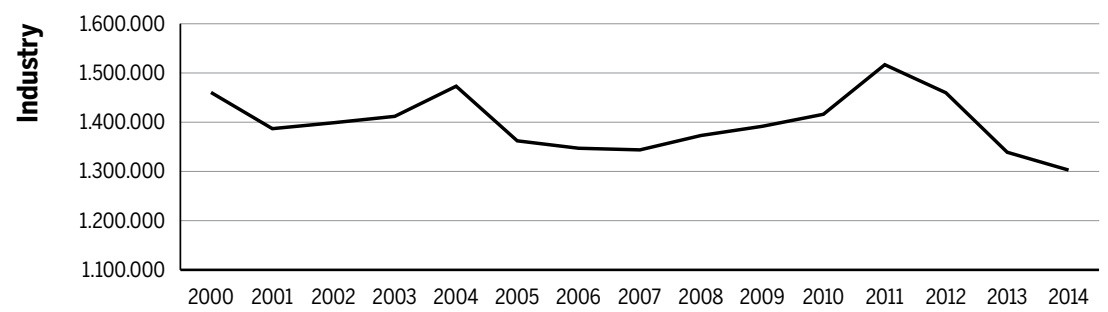

Number of employees

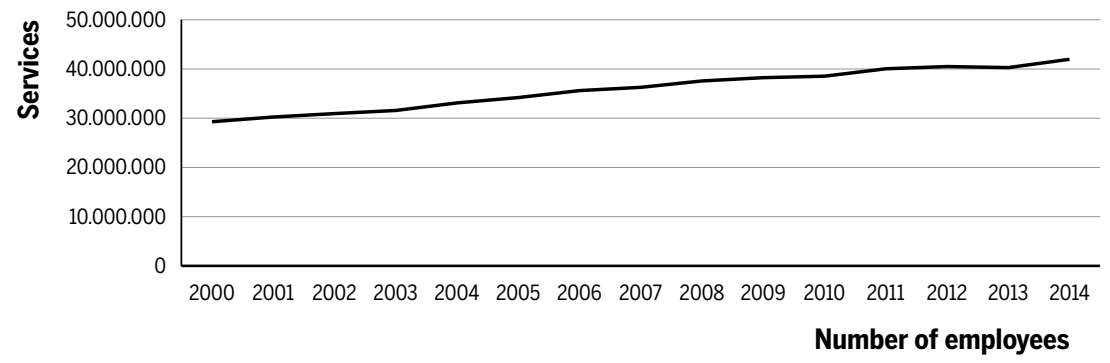




\section{Capital (K)}
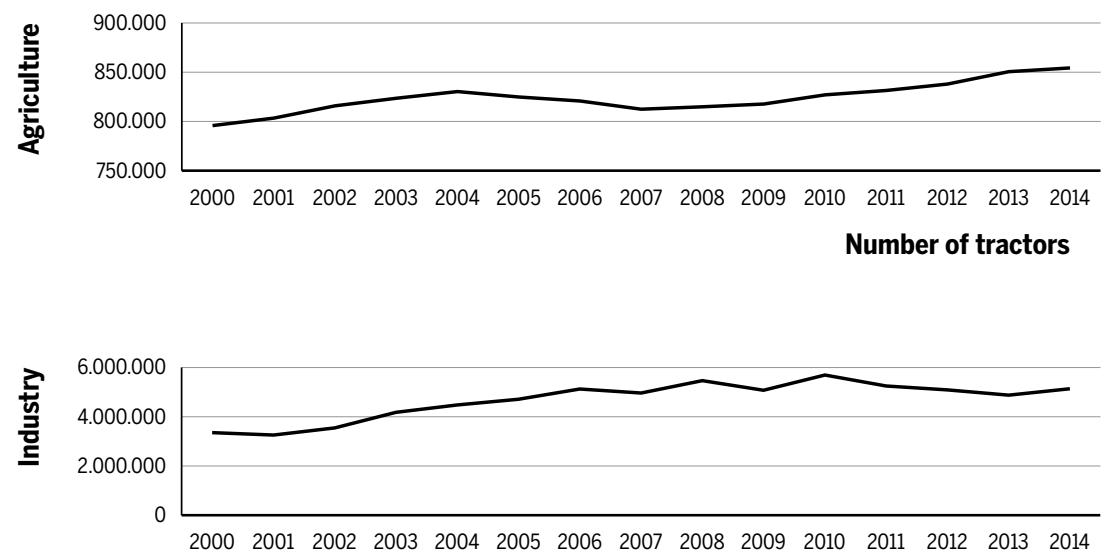

Electricity (BRL of 2013)

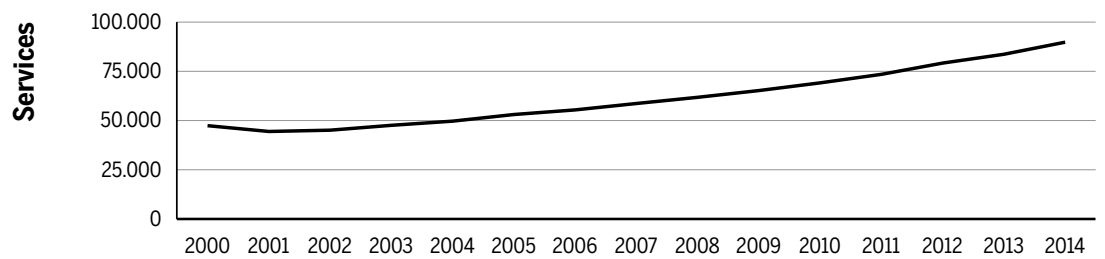

Electricity (Gwh) 
Table A3 Labor productivity (R \$/employee, annual average, 2000-2014)

Shaded cells: above average productivity

\begin{tabular}{|c|c|c|c|}
\hline State & Agriculture & Industry & Services \\
\hline RO & 22.855 & 21.647 & 27.465 \\
\hline$A C$ & 26.943 & 13.815 & 28.248 \\
\hline AM & 11.340 & 109.717 & 36.096 \\
\hline RR & 11.566 & 18.815 & 29.883 \\
\hline PA & 11.092 & 36.523 & 29.356 \\
\hline AP & 12.166 & 27.015 & 29.678 \\
\hline TO & 25.907 & 18.192 & 23.861 \\
\hline MA & 10.068 & 34.800 & 24.866 \\
\hline $\mathrm{PI}$ & 5.001 & 21.457 & 22.960 \\
\hline CE & 6.391 & 21.248 & 26.756 \\
\hline RN & 8.021 & 22.594 & 31.953 \\
\hline PB & 5.932 & 21.348 & 23.622 \\
\hline $\mathrm{PE}$ & 5.130 & 27.873 & 33.608 \\
\hline $\mathrm{AL}$ & 7.706 & 16.602 & 28.150 \\
\hline SE & 6.324 & 34.716 & 32.508 \\
\hline BA & 7.442 & 81.134 & 30.140 \\
\hline$M G$ & 20.301 & 45.440 & 41.288 \\
\hline ES & 19.386 & 48.506 & 46.277 \\
\hline RJ & 15.614 & 83.390 & 60.972 \\
\hline SP & 22.939 & 52.717 & 68.864 \\
\hline PR & 24.357 & 39.829 & 53.022 \\
\hline SC & 22.767 & 28.566 & 51.848 \\
\hline RS & 24.288 & 38.046 & 50.225 \\
\hline MS & 41.443 & 37.243 & 42.702 \\
\hline MT & 54.063 & 38.387 & 39.936 \\
\hline GO & 40.116 & 33.354 & 36.110 \\
\hline DF & 18.027 & 33.251 & 72.946 \\
\hline Average & 18.044 & 37.268 & 37.901 \\
\hline
\end{tabular}

